\title{
Digital and Multimodal Literacies in Foreign Language Learning: theories and application
}

\author{
19 \\ Elisa Da Lio \\ Università Ca' Foscari di Venezia \\ elisa.dalio@unive.it
}

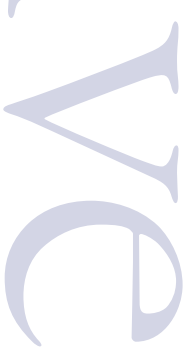

Ta članek sledi razvoju pojma pismenosti v vsej njegovi razvejanosti in analizira njegove prednosti ter slabosti, ki jih razkrivajo raziskave, opravljene na področju učenja jezikov. Poudarek je na razmerju med raziskavami in poukom jezikov, kjer se zdi, da je spodbujanje pluralne, multimodalne in digitalne pismenosti še vedno težko dosegljivo. Ta članek opozarja na primerjavo med najnovejšimi študijami primerov na področju jezikovnega izobraževanja in specifičnimi učnimi cilji za poučevanje in učenje pismenosti. Zaključi se s predlogom novih smernic za nadaljnje raziskave.

Ključne besede: opismenjevanje, multimodalnost, digitalna pismenost, angleščina kot tuji jezik, poučevanje

This article traces the evolution of the term literacy in the plurality of its branches, analysing its strong points as much as the critical aspects highlighted by research in the field of language education. The emphasis is placed on the relationship between literacy and language classrooms, where the promotion of plural, multimodal and digital literacies still seems difficult to achieve. This article calls attention to the comparison between the most recent case studies in the language education field and the specific learning objectives for literacy teaching and learning. It concludes by suggesting new directions for further research.

Keywords: Literacy, Multimodality, Digital Literacy, EFL, Teaching

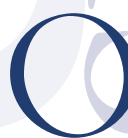
ver four decades of studies have witnessed literacy go from being synonymous with 'alphabetization' to being considered as "the ability to identify, understand, interpret, create, communicate and compute, using printed and written materials associated with varying contexts" (UNESCO 2004). It has recently emerged as a pivotal term in language teaching and learning, as a plural set of skills and abilities that allow individuals to use specific languages for particular purposes and through a variety of media within socially complex multimodal contexts. The fact that literacy is an ever evolving, elastic concept implies that clear, universally accepted definitions are diffi- cult to provide, and that research has been moving in several different directions to try and cover as many aspects as possible. It is a very vast field, which affects every educational subject as it is a prerequisite of sorts, and calls into question aspects of social background, first of all economically, as it requires for everyone to have access to the same tools and devices (Fairlie et al.2012; Urbančíková et al. 2017), as well as culturally and identity wise, as it may involve the development of literacies in a language other than one's native one (Dooley 2008; Danzak 20II; Ntelioglou 2012). Also, a branch mainly related to the wide setting of digital skills is being expanded: as a result, many studies in this area focus on ex- 
ploring the difference between 'digital native' students and 'immigrant' teachers (Rajeswaran 2019), while others investigate the new role of learners as content creators (Lenhart and Madden 2005), or the different types of texts and discourses. Within the classroom, many have achieved positive results by experimenting with one or more tools and different approaches to see if and how different ways of making meaning could be helpful to the students, stimulating their motivation and different learning styles. All these different areas have long been the subject of research and observation. However, they remain sectoral, and it is difficult to obtain a complete picture of what the situation is today, in the light of the studies conducted in the field of language education, when it comes to literacy in foreign language teaching and learning within a formal educational context. The present research project stems from the observation of an open question: "what we do in schools under the rubric of literacy, and particularly what we measure in our literacy assessments, has not caught up with [the] profound changes" that have been affecting society and language education (Cope et al. 20II). Not only that, there seems to exist a significant gap between theoretical multiliteracies approaches and common assessment practices (Botelho et al. 2014). It is therefore necessary to explore if and how the school system is managing to keep up with the research conducted in this field, how aware teachers are of such any discrepancy, and how to attempt to reduce the distance between theory and practical application.

\section{The concept of literacy}

The first attempt to summarise systematically the growing corpus of research on literacy education dates back to Edmund Burke Huey's work in 1908. Deriving from the Latin word littera, it was traditionally defined as the ability to read and write, perhaps also referring to numeracy. Not much changed during the following decades, until 1958, when UNESCO provided one of the first and most quoted definitions of literacy, by stating that "a literate person is one who can, with understanding, both read and write a short simple statement on his or her everyday life" (UNESCO Educational Sector 2004). The notion slowly started to widen a little, mostly because of a tendency which spread in the sixties and seventies that considered literacy as a useful way of developing professional skills as well as promoting social growth and political awareness. UNESCO offered a new definition of functional literacy in 1978 , which said that "a person is functionally literate who can engage in all those activities in which literacy is required for effective functioning of his group and community and also for enabling him to continue to use reading, writing and calculation for his own and the community's development" (UNESCO 1978).

While most definitions still mainly acknowledge the basic skills which allow people to read, write and calculate, the new approaches to literacy began to focus on several different aspects: literacy was thus identified, depending on the circumstances, as the ability of each individual to properly use such skills in order to achieve their communicative goals; as a set of social and cultural practices which change according to different contexts; and as a tool for critical thinking. Setting four "pillars of education for the future" in his Report, Delors focuses on learning to know, do, be, and live profitably with others (Delors 1996).

The notion being this wide, it gradually became clear that the acquisition and development of literacy could not be limited to a specific learning environment or purpose, but rather it is a lifelong process which involves a continuum of learning, is not age-related, and takes place before, during, and after school, regardless of how formal the learning environment is. It is the foundation upon which any other learning occasion rests: according to the definition UNESCO provided in 2003 , "Literacy is the ability to identify, understand, interpret, create, communicate and compute, using printed and written materials associated with varying contexts. Literacy involves a continuum of learning in ena- 
bling individuals to achieve his or her goals, develop his or her knowledge and potential, and participate fully in community and wider society" (UNESCO 2004 and 20II). Above all, literacy is plural: not just because of its evolving definitions, but because it concerns the uses people make of it as a means of communication, practiced in different context for specific purposes and through specific languages, via a variety of different media.

\section{Literacy is plural}

The plurality of literacies is not a new concept per se: two years after coming together to re-examine the basics of language learning and teaching, the New London Group (NLG) published the manifesto "A Pedagogy of Multiliteracies: Designing Social Futures" (1996). Along with several theorists challenging the notion of a singular literacy before them, the group argued that a broader view of literacy was necessary, one which was not confined to the coding of oral or written language, but which was instead able to take into account the proliferation of different channels and methods of communication brought in by the new information and multimedia technologies, and the growing linguistic and cultural diversity due to the ever more frequent transnational migrations. The term "Multiliteracies" was coined to respond to these two emerging significant changes, and to address the inherently plural nature of literacy, in terms of discourses and texts as well as of languages and media. Cope and Kalantzis, as former members of the NLG, explain how such a term deals with the multiple forms of expression, linguistic representation, and communication channels and media, while reflecting the increasing diversity that contemporary multicultural societies offer (Cope \& Kalantzis 2000).

While multiliteracies was initially formulated as a general principle for schools and teachers to follow, the NLG proposed a new literacy pedagogy, where literacy and literacy teaching no longer focused on "what texts mean in an absolute sense, [but] what people mean by texts, and what texts mean to people who belong to different discourse communities" (New London Group 1996). Learners are therefore not just mere decoders of language, but creators of meaning influenced by the social and cultural context surrounding them, by the resources available to them, and by their own attitudes and life experiences, which is why language teaching, be it native, second, foreign, needs to support and promote different types of texts and modes of expression. The pedagogy of multiliteracies identified six elements as pivotal in the meaning-making process (linguistic, visual, audio, gestural, spatial and multimodal) and suggested the interaction of four components: situated practice, overt instruction, critical framing and transformative practice. This basically means reframing the four knowledge processes of experiencing, conceptualising, analysing and applying, in order to create "learning environments in which the blackboard, textbook, exercise book and test are augmented and at times replaced by digital technologies" (Kalantzis \& Cope 2005). According to Yi (2014), engaging English Language Learners (ELLs) in multiliteracies-based pedagogies could be beneficial, but such benefits are not widely acknowledged yet.

The element of plurality addresses several different issues, including the formality of the learning environment, the more or less traditional literacy practices, and so on, but, according to Cole and Pullen (2009), it also strongly relates them to the new technological modes of representation.

\section{Literacy is multimodal}

The notion of multiliteracies is exactly what puts the concept of multimodality in the foreground as a key construct within literacy research (Kress \& van Leeuwen 200I). Multimodality is concerned with how individuals make meaning and how it is constructed through several different modes and resources which can be both combined and presented via multiple different media. Multimodality, Rowsell and Walsh explain, "comes first in that it informs how we 
make meaning, and multiliteracies, as a possible pedagogy, gives us tools for doing so" (Rowsell and Walsh 20II). In an era in which traditional printed texts can no longer be considered as the primary carriers of meaning (Kress 2009), it is necessary to re-examine previous assumptions about learners, text types and discourses, as well as language teaching and learning modalities.

Kress and van Leeuwen distinguish between 'mode' and 'medium': while the latter is the material selected to carry the message and make it available to others (like a printed book, a video, and so forth), a mode, in Kress' words, is "a socially shaped and culturally given resource for making meaning" (Kress 2009). Not every multimodality related study focuses as strongly on the social aspects of modes, but they are still widely considered as sets of resources for the interaction with the outside world and the construction of meaning, through sensory systems such as sight, hearing and touch and different media, like books, games or digital devices. Multimodality, therefore, refers to the interaction of three or more sensory systems in which different modes combine to work towards a single communicative intent. Visual meanings, for example, include images, page layouts and colours; audio modes focus on sounds, music, rhythm or tone; spatial modes refer mainly to the learning environment, while gestural designs concern gestures and behaviours, body language and proximity; tactile meanings require interacting with objects and props, and, finally, linguistic modes involve lexicon and grammatical structures, in both oral and written dimensions. What multimodality does, then, is combine different elements from different meaning-making modes and present them through different media (Bearne \& Wolstencroft 2007).

Multimodality researchers have been exploring different perspectives related to multimodal literacy teaching and learning, from the influence of social aspects, to convergence, which analyses whether and to what extent different modalities can be considered interconnected and interdependent (Walsh 2008). In any case, if we mainly concentrate on research in the field of (foreign) language education, the most relevant aspect lies in understanding how different representational and communicational resources allow for meaning to be constructed, and how such a multimodal approach can affect the learners' motivation and different learning styles. Castro and Peck (2005) claimed that learning styles (visual, auditory, tactile, kinesthetic, group and individual) have the power to either help or hinder language classroom achievements, and various studies (Abdulwahed \& Nagy 2009; Gaur, Kohli \& Khanna 2009; Pfeifer \& Borozan 20II) report that learning environments oriented towards learning style awareness and matching are usually more valid and successful than others. Nevertheless, most lessons and teaching methods are still usually geared towards auditory and visual learners. Since the six modes mentioned above manage to bring into play several sensory inputs related to different learning styles, a multimodal approach is better suited to a heterogeneous class, allowing students to use their dominant modalities while reinforcing the others.

\section{Literacy is digital}

In such circumstances, technology proves to be an extremely valuable tool. The recent impact of digital technologies on text production has helped to highlight the multimodal character of texts and the fact that focusing on language alone cannot possibly be enough to explain meaning-making. Technology, Brown states, is a tool which provides language learners with multiple opportunities to have "genuine, meaningful communication" in the target language (Brown 2007), and this is where the concept of digital literacy fits. It was first introduced by Gilster (1997), who defined it as the "ability to understand and use information in multiple formats from a wide range of sources when it is presented via computers" (Gilster 1997, I), but he failed to provide a list of skills and competences related to it, as it was not associated with formal education, but rather seen as a useful life skill. The term had to find its place among several already existing 
denominations, such as "network literacy" (McClure 1994, synonymous with internet literacy and focused on digital information), "informacy” (Neelameghan 1995, which combines information with traditional literacy), or "mediacy" (Inoue, Naito \& Koshizuka 1997, implying the ability to work with a variety of different media). Not only that, it also needed to compete with an ever-growing list of new terms like computer literacy, ICT literacy, e-literacy, media literacy and so on. Finding a unique definition was, and still is, extremely complicated, as this field continues to evolve to keep up with technological advancements, such that many more definitions have been proposed over the years: Martin said that

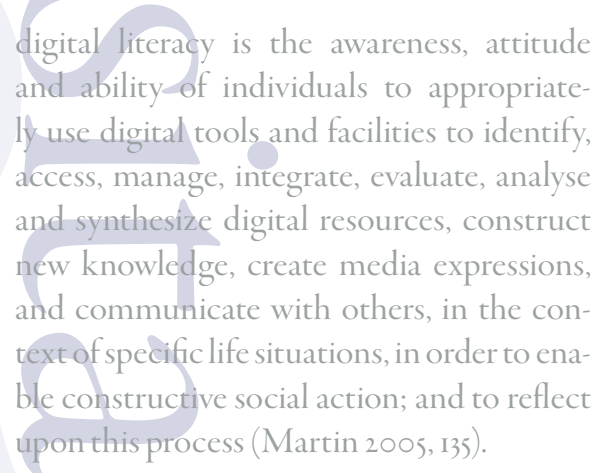

To be digitally literate, in Ferrari's words, is the ability to understand media, to use them, as well as different tools and devices, to successfully communicate with others, and to be able to critically evaluate new information (Ferrari 20I2).

In every definition, digital literacy is described as a highly plural set of skills, so that some researchers even call them digital literacies (Ng 2012; Dudeney, Hockly \& Pegrum 2014). Also, no matter how many definitions we pick, they all address "the growing range of digital communication channels" (Dudeney et al. 20I4) to which we apply our ability to process information in a multimodal environment (Gilster 1997, Rivoltella 2008, Meyers et al. 2013). It has become, according to UNESCO, an umbrella term of some sort, which includes a set of basic skills, such as searching, manipulating, synthesizing and evaluating digital content (information literacy), interacting with different types of media (media literacy), communicating via both traditional and innovative means (communication literacy), and so on. Also, many different terms are still used somewhat interchangeably: some mention "skills", other "competences", or "understandings", as well as "aptitudes", "knowledge", and, of course, "literacies". Rather than a mere list of skills, however, it is increasingly described as those capabilities which enable individuals to live and work in a constantly changing digital society, thus becoming functional digital citizen. This perspective, where the practices and tools of digital literacies are seen as deeply embedded in a specific context, is strictly linked with the multiliteracies paradigm (see above). In the field of language education, digital literacy can prove beneficial for learning, not only because it provides access to a broad range of resources and tools, but also because it calls into question the idea according to which learners are referred to as 'digital natives' (Prensky 200I) or 'net geners' (Turner \& Carriveau 2010), that is to say, native speakers of digital languages, but more will be said about this below.

\section{Case studies and emerging issues}

In its Ad Hoc Committee, the Modern Language Association called attention to the importance of producing students who are not only able to function as capable interlocutors in the target language, but are "trained to reflect on the world and themselves through the lens of another language and culture" (MLA 2007). Despite the fact that this field is still largely dominated by communicative language teaching, many studies have since started to venture into a literacy-oriented framework: several publications (e.g., Paesani 2006; Péron 2010; Troyan 2016), for example, have examined the relationship between reading and writing within a multiliteracies paradigm. Troyan's work was one of the few attempts to bring a multiliteracies approach in line with the American Council on the Teaching of Foreign Languages (ACTFL)'s Standards, which measure the skills that learners need to apply in order to bring a global competence 
to their future careers and experiences, thus encouraging lifelong learning. Other studies have worked with filmic media in order to better develop translingual and transcultural competences while promoting critical literacy and enhancing multimodal competences (Goulah 2007; Kaiser 2011; Brown, Iwasaki \& Lee 2016). Ganapathy (2014) has investigated whether a Multiliteracies Approach is able to transform conventional learning settings into a more relevant environment. This study confirmed the effectiveness of said approach, as did previous findings from related studies (Shuhaimi 2004; Grabill \& Hicks 2005; Tan \& Mc William 2009), and implied that it should be considered for future curriculum organization in the ESL classroom. Choi (2015), for example, found that the multiliteracies curriculum increased the students' motivation to read. However, the road towards multimodal literacies in the classroom is still a long one: while the multiliteracies pedagogy has been gaining attention when it comes to some of the more commonly taught languages, Brown et. al (2016) argue that more studies need to be conducted in the case of less commonly taught ones. Also, despite going through significant changes already, the fact that most of the current available textbooks are not structured in such a way as to meet the requisites of a multiliteracies context clearly increases the problem. The need to implement literacy-oriented foreign language programmes is highlighted by suggesting that instructors supplement existing textbooks with their own multiliteracies-oriented lessons (Barrette et al. 20I0, Paesani et al. 2015) and target strategies to fit a multiliteracies framework. One of the first textbooks to introduce teachers and language educators to a multiliteracies frame of reference was published by Paesani, Allen, and Dupuy in 2015.

As for multimodality, the phenomenon is approached through different theoretical perspectives, but they all more or less hinge on four basic assumptions (Jewitt 2014), according to which all communication is multimodal; a merely linguistic analysis cannot adequately ac- count for meaning; different modes use different resources to fulfil communicative needs; and modes (such as visual, audio, gestural) concur together, in different ways, to make meaning. In the specific context of language education, multimodal practices could promote content learning and help young learners develop academic literacy as well as multimodal communicative competence (Early and Marshall 2008; Pirbhai-Illich, Turner and Austin 2009). Smythe and Neufeld (2010), however, argue that different multimodal aspects are not yet easily integrated with the learning outcomes prescribed by the single national curricula frameworks. Godwin-Jones (2016), for example, calls attention to the increasing importance of digital literacy, pointing out that teachers should be "preparing students for a globalized, multilingual world", and the International Society for Technology in Education [ISTE] (2OI2), defining the standards of excellence with technology for various stakeholders in education, developed five ISTE Standards for teachers to follow in order to engage their students while promoting digital work and learning. Within a literacy education environment, Bogard \& McMackin (2OI2) defined innovation with technology as those "practices for making meaning that transcend language and include photography, art, music, video, or audio representations", including student-produced products, such as digital stories (McAdams \& Gentry 2014) and movies (Young $\&$ Rasinski 2013). Integrating digital gaming and social media can also increase the students' engagement with texts (Reinhardt, Warner and Lange 2014; Warner \& Richardson 2017). Leung et al. (2OI2) and Lopez-Islas (2013), amongst others, analysed the relationship between Internet literacy and digital literacy, respectively, and academic performance: although other case studies ended up obtaining unclear results, they both found that better ICT access and knowledge can positively impact on academic performance.

The examination of recent existing studies has certainly provided us with a clearer picture of the direction research is moving in, but 
has also highlighted some issues. First of all, the sectoral nature of said studies, which often focus on exploring an extremely specific aspect, like the effect of a particular device (such as smartphones in Bromley 2012, or tablets in Hutchison, Beschorner \& Schmidt-Crawford 2012; or Northrop \& Killeen 2013) or their application (Twitter, in Morgan 2014) on educational outcomes within the learning environment; the use of multilayered and multimodal texts in language teaching, which would allow learners to better interpret the social, ideological and cultural elements embedded in every specific text; literacy as a basis to further integration, while simultaneously encouraging the students' to strengthen their individual ethnolinguistic identity, and promoting heritage language maintenance (Parra, Otero, Flores \& Lavallée 2017; Zapata 2017), and so on. This does not allow to easily obtain a complete overview of the situation, essential when trying to take into account so many different factors. Not only that, we must also bear in mind the fact that recent research has shown a tendency to focus on the digital or on the multimodal, overlooking how complex it actually is to introduce contemporary literacies in the classroom; furthermore, parts of these studies require constant updating and revaluation, given how quickly technologies tend to become obsolete.

Moreover, while most studies generally confirm the positive effect of multimodal and digital literacies in a learning environment, they have also brought to light a series of problems that require further analysis. For example, the fact that students seem to prefer to use technology mainly for personal and social reasons, despite being able to use it quite easily, and rarely turn to online tools for academic purposes (Ophus \& Abbitt 2009; Ng 2012; Ivala \& Gachago 20I2; Mok 20I2). Surveys focusing on the use of digital devices by foreign language students reveal that not everyone considers themselves to be digital natives (Williams, Abraham and Bostelmann 20I4). Gui \& Argentin (20II) and Gobel $\&$ Kano (2014) found that testing the students' digital skills (in terms of theoretical knowledge, operational skills and assessment skills) showed that they achieve better results in operational skills but are limited in the use of certain types of technologies. Also, many learners rarely question the accuracy of information and have a tendency to equate the amount of information with its quality (Walraven, Brand-Gruwel \& Boshuizen 2009; Goldman et al. 2012; Barzilai \& Zohar 2012; Zhang 2013; Coiro, Coscarelli, Maykel and Forzani 20I5). According to a recent report ${ }^{\mathrm{I}}$, digital competence levels in European children and adolescents remain inadequate, and another study ${ }^{2}$ from 2014 indicates the existence of a wide discrepancy between young learners' self-assessment and their actual knowledge of computer skills. Son, Park and Park (2017), for example, report that their participants assessed their own abilities very positively, despite a low mean score of 5.4 out of 10 in the general digital literacy test they took. Another survey conducted among Italian university students revealed that most students have very low digital security skills when it comes to connection, authorizations, installations, access protections. ${ }^{3}$ In the context of language learning, some students still prefer the use of paper-based materials (Fratter \& Altinier 2017; Fratter 2018 and 2019), while the multimedia materials are generally chosen for an in-depth analysis of the paper book. The reasons behind this preference concern different aspects: general order of materials, sequence of contents, practicality in carrying out each activity.

\section{Classroom literacy and learning objectives}

Demographic and technological changes are creating new "multicultural" societies and providing access to huge amount of information anywhere, at any time. As can be seen from the

\footnotetext{
NMC and the European Commission "Horizon Report Europe: 2014 Schools Edition", 2014

"An online study makes it possible - new ECDL - reframing the climate of public opinion", Austria, 2014.

Tech and Law Center, "Security of the Digital Natives", Italy, 20 I 4.
} 
studies conducted in recent years, all literacies are built on the four traditional literacy skills of reading, writing, speaking and listening (Meyers et al. 2013). However, when it comes to language education, a much broader definition of literacy is required nowadays, one that takes said changes into account to re-examine how learners, texts, culture and language learning are traditionally described. In response to the rapidly changing learning contexts, Leu, Kinzer, Coiro and Cammack (2004) suggested that the new literacies for the $2 \mathrm{I}^{\text {st }}$ century need to include the necessary skills and strategies to successfully adapt to the ever evolving information and communication technologies, which influence all areas of our lives. However, this is not the case yet, as classroom literacies are still extremely flat and usually reduced to print-based resources: Lotherington first describes two-dimensional literacies as "the static, linear, paper-based reading and writing agendas of school language and literacy curricula and assessment" (Lotherington 2010). They undermine the authenticity of the learning experience and do not stimulate the students' motivation and different learning styles.

Oz, Demirezen and Pourfeiz' study (2015), for example, explored the relationship between language learners' attitudes toward foreign language learning and the use of technology in their learning environment. They confirmed the existence of a positive connection between the two and found that mobile phones and laptops, owned by a significant majority of the participants (roughly nine out of ten), are usually their preferred tools for foreign language learning. Similar results were obtained by Öz (2015). Also, learners guided by digitally fluent teachers seem to improve their conceptual skills, achieve better results in verbal and non-verbal communication, and increase their problem-solving abilities (Keengwe \& Onchwari 2009). Teachers are often accused of not implementing ICT and thus failing to acknowledge and engage these new dimensions of literacy, either because of their age (Raman \& Yamat 20I4) or lack of training. Internalising previous research (Simjanoska 2017;
Palalas 20II; Gaudreau et al. 2013; Kurniawati et al. 2018), Rajeswaran (2019) investigated the use of mobile phones in academic English teaching, to find whether or not teachers are competent and comfortable enough to handle digital devices. The research revealed that many teachers are not able to deal with technological challenges without proper training. Even where technological devices are accessible, though, most schools are not yet structured in such a way as to make technology an integral part of the learning process, so that most of the teaching takes place through traditional supports, thus underutilizing or ignoring altogether the potential of such diverse means. Kress, who is an advocate for multimodality, argues that teaching literacy only as a stable set of linguistic conventions is no longer sufficient, in the face of the multiple modalities and communication platforms society offers.

Also, much research focuses on isolated case studies which experiment with different tools and devices and introduce different approaches, regardless of the fact that the school system faces a very different reality: the ultimate example of multimodal literacies in the language classroom still consists of the dual modalities of text and image (if the school resorts to the language laboratory, it might widen enough to include audio resources) thus excluding the multiple different modalities that construct meaning, learning and understanding in this globalized, digital age. In 2004, Valdés stated that

$$
\begin{aligned}
& \text { the view that there are multiple literacies } \\
& \text { rather than a single literacy, and that these } \\
& \text { literacies depend on the context of the situ- } \\
& \text { ation, the activity itself, the interactions be- } \\
& \text { tween participants, and the knowledge and } \\
& \text { experiences that these various participants } \\
& \text { bring to these interactions, is distant from } \\
& \text { the view held by most L2 educators who still } \\
& \text { embrace a technocratic notion of literacy } \\
& \text { and emphasize the development of decon- } \\
& \text { textualized skills (Valdés } 2004,79 \text { ). }
\end{aligned}
$$

In the specific learning objectives indicated by the Italian Ministry of Education (ministeri- 
al decree number 2 II of 7 October 2010) as regards foreign language teaching and learning in upper secondary schools, no reference is made to the concept of literacy, nor to the many possible different methods and approaches related to it, proving not much has changed in the last fifteen years. Technology also is not taken much into consideration: it is only highlighted how, over their last two school years, the students will be asked to use the new information and communication technologies to do research, deepen linguistic and non-linguistic topics, express themselves creatively and communicate with foreign interlocutors.

\section{Conclusions and direction for future research}

Analysing and selecting theories and research has brought to our attention how wide this field actually is and how many branches have already been developed, each taking specific subtopics into consideration. However, it has also highlighted some critical issues, as we have seen before, as well as some discrepancies between the research and studies that have been carried out within the framework of language education and the reality of foreign (second) language learning within the school system. In order not to create a wide fracture between theory and mainstream practice, it is necessary for future research to focus on the effective application of the results obtained from the many studies in the everyday school reality. It would certainly be important to analyse how a plural approach to literacies might affect groups of students with different cultural and linguistic backgrounds, or the management of mixed-ability classes and so forth, but above all it is necessary to understand what is actually being done in the language classroom and how to speed up the transition from a still relatively flat literacy approach to a more complex, modern and multimodal one. Being aware of the specific learning objectives that the school system could establish for foreign (second) language learning vis-à-vis literacy could prove useful for future research focussing on the gap between the evolu- tion of recent studies within the language education field and the approaches introduced in the classroom to help students develop multilayered, digital and multimodal literacies. Moreover, in a situation like the present one, the spread of a global pandemic has forced schools and teachers everywhere to willingly or unwillingly put into practice different types of teaching, methods and approaches, and has demonstrated the importance (if not the essentiality) of different, wider and elastic skills, which deal with different tools and devices and which conceive both teaching and learning as the result of a multilayered set of modalities, sensory systems and semiotic modes. Being more prepared in this regard would certainly have facilitated such transition, and would have made it a smoother, educationally valid experience, instead of a difficult palliative. The first step, therefore, is to try to compare what current research suggests and what schools are actually working on, to see what needs to be adjusted. Further research in this field could therefore move in the direction of trying and concretise, within the limits of the restrictions dictated by programs, curricula and so on, those theories that, for now, have largely remained abstract, thus allowing the school system to keep up with a rapidly changing society.

\section{Summary}

This article explores the concept of literacy in the context of foreign and second language learning in a formal educational context, reporting some of the best-known definitions and highlighting their evolution over time. Specifically, the aspects of plurality and multimodality vis-à-vis literacy are first taken into consideration, before moving on to the digital environment, and to the analysis of the role literacy holds within the school system. A comparison is made between the specific learning objectives for literacy teaching and learning in upper secondary schools and the cases taken into account by the most recent and significant studies in the field of language education. The author suggests the presence of a gap between these two different areas, drawing a few considerations on the direction that future research could take in order to verify the actual existence of said 
gap and attempt to reduce it by introducing different, more varied approaches into the language classrooms and helping students develop multilayered, digital and multimodal literacies.

\section{Povzetek}

Članek preučuje koncept pismenostiv okviru učenja tujih in drugih jezikov v formalnem izobraževalnem kontekstu z navajanjem nekaterih najbolj znanih definicij in pregledom njihovega razvoja skozi čas. Natančneje, najprej preučimo pismenost na podlagi vidikov pluralnosti in multimodalnosti, šele nato se premaknemo $v$ digitalno okolje in analiziramo vlogo pismenosti v šolskem sistemu. Naredimo primerjavo med specifičnimi učnimi cilji poučevanja in učenja pismenosti v srednjih šolah in primeri, ki so jih upoštevale najnovejše in najpomembnejše raziskave na področju jezikovnega izobraževanja. Avtorica predpostavlja obstoj velike vrzeli med tema dvema različnima področjema, pri čemer poda nekaj usmeritev o tem, v katero smer bi lahko vodile prihodnje raziskave. Vse to z namenom, da bi preverili dejanski obstoj omenjene vrzeli in jo poskušali zmanjšati z uvajanjem različnih, bolj raznolikih pristopov v jezikovne učilnice in pomagali dijakom pri razvoju večplastne, digitalne in multimodalne pismenosti.

\section{References}

Abdulwahed, M.; Nagy, Z. K. 2009. "Applying Kolb's experiential learning cycle for laboratory education." Journal of engineering education, 98-3: 283-294.

Barzilai, S. and Zohar, A. 2012. "Epistemic thinking in action: Evaluating and integrating online sources." Cognition and Instruction, 30(I): 39-85.

Barrette, C. M., K. Paesani, and Kimberly Vinall. 2010. "Toward an integrated curriculum: Maximizing the use of target language literature." Foreign Language Annals, 43.2: 216-230.

Bearne, E.; Wolstencroft, H. 2007. Visual approaches to teaching writing. Paul Chapman Publishing.

Bogard, J. M.; McMackin, M. C. 2012. "Combining traditional and new literacies in a 2 Ist-century writing workshop." Reading Teacher, 65(5): 313-323.

Botelho, M. J., J. Kerekes, E. Jang, and S. StaggPeterson. 20I4. "Assessing multiliteracies: Mismatches and opportunities." Language and Literacy, I6(I): I-20.

Bromley, K. 2012. "Using smartphones to supplement classroom reading." Reading Teacher, 66(4):340-344. doi:10.1002/ TRTR.oII30

Brown, H. D. 2007. Teaching by principles: An interactive approach to language pedagogy (3rd ed.). White Plains, NY: Pearson Education.

Brown, L., N. Iwasaki, and K. Lee. 2016. "Implementing multiliteracies in the Korean classroom through visual media." In Multiliteracies in world language education, edited by Y. Kumagai, A. López-Sanchez, and S. Wu,, I58-18I. Oxon, UK: Routledge.

Castro, O., Peck, V. 2005. "Learning styles and foreign language learning difficulties." Foreign Language Annals, 38.3: 401-409.

Choi, J. 2015. “A heritage language learner's literacy practices in a Korean language course in a US university: From a multiliteracies perspective." Journal of Language and Literacy Education, II(2): II6-I33. http://jolle.coe.uga.edu/wpcontent/uploads/2015/10/Article-6_ChoiFINAL.pdf

Coiro, J., Coscarelli, C.; Maykel, C., Forzani, E. 2015. "Investigating Criteria That Seventh Graders Use to Evaluate the Quality of Online Information." Journal of Adolescent \& Adult Literacy, 59(3): 287297. doi:10.1002/jaal.448

Cole, D.; Pullen, D. 2009. Multilitercies in motion: current theory and practice. New York: Routledge.

Cope, B., Kalantzis, M. 2000. "Designs for social futures." In Multiliteracies: Literacy learning and the design of social futures, edited by B. Cope and M Kalantzis, 20334. London: Routledge. 
Cope, B., Kalantzis, M., McCarthey, S., Vojak, V., and S. Kline. 2011. "Technology mediated writing assessments: Principles and processes." Computers and Composition, 28(2): 79-96.

Danzak, R. L. 20ı. "Defining identities through multiliteracies: EL teens narrate their immigration experiences as graphic stories." Journal of Adolescent \& Adult Literacy, 55(3): 187-196.

Delors, J. 1996. "Learning: The Treasure Within." Report to UNESCO of the International Commission on Education for the Twenty-first Century, UNESCO.

Dooley, K. 2008. "Multiliteracies and pedagogy of new learning for students of English as an additional language." In Multiliteracies and expanding landscapes: New pedagogies for student diversity, edited by A. Healey, IO2-I25. South Melbourne, Australia: Oxford University Press.

Dudeney, G., Hockly, N., and Pegrum, M. 2014 . Digital Literacies. Harlow: Pearson.

Early, M., and Marshall, S. 2008. "Adolescent ESL students' interpretation and appreciation of literary texts: a case study of multimodality." Canadian Modern Language Review, 64: 377-397.

Fairlie, R. W. and R. A. London. 2012. "The Effects of Home Computers on Educational Outcomes: Evidence from a Field Experiment with Community College Students." The Economic Journal, I22: 727-753.

Ferrari, A. 2012. "Digital Competence in Practice: An Analysis of Frameworks.” Luxembourg: Publications Office of the European Union, OECD DeSeCo. 2005. The Definition and Selection of Key Competencies: Executive Summary. Retrieved from http://www.oecd.org/ pisa/35070367.pdf.

Fratter I., and M. Altinier. 2017. "Il pubblico degli studenti internazionali e le loro abitudini tecnologiche nei CLA: quale offerta formativa di italiano L2 per loro?"
In Diffusione della lingua italiana e ruoli dei Centri Linguistici di Ateneo, edited by P. Guaragnella, R. Abbatticchio and C. Williams, 89-106. Atti del convegno AICLU, Bari 9-10 novembre 2015. Lecce: Pensa Multimedia.

Fratter, I. 2018. "Gli studenti universitari di italiano L2 sono digital learners?” In Nella classe di italiano come lingua seconda/straniera. Metodologie e tecnologie didattiche, edited by M. C. D'Angelo and P. Diadori, 17-31. Firenze: Franco Cesati Editore.

Fratter, I. 2019. "Preferenze per i materiali di studio in italiano L2: la carta o il digitale?” Italiano LinguaDue, I: 89-97.

Ganapathy, M. 20I4. "Using Multiliteracies to Engage Learners to Produce Learning." International Journal of e-Education, $e$-Business, e-Management and e-Learning, $4(6): 4 \mathrm{IO}^{-} 422$.

Gaudreau, P., D., Miranda, and A. Gareau. 2013. "Canadian university students in wireless classrooms: What do they do on their laptops and does it really matter?" Computers \& Education, 70: 245-255. Retrieved from https://reader.elsevier.com/ reader/sd/pii/So360131513002546?

Gaur, S. P., G. Kohli, and K. Khanna. 2009. "Learning Centred Innovation in management education: Kolb's ELT." The International Journal of Learning, I5.

Gilster, P. 1997. Digital Literacy. Wiley Computer Pub.

Gobel, P., and M. Kano. 20r4. "Mobile natives: Japanese university students' use of digital technology." In Computer-assisted language learning: Learners, teachers and tools, edited by J.-B. Son, 2I-46. Newcastle upon Tyne, UK: Cambridge Scholars Publishing.

Godwin-Jones, R. 2016. "Looking back and ahead: 20 years of technologies for language learning." Language Learning \& Technology, 20(2): 5-I2. Retrieved 
from http://llt.msu.edu/issues/june20ı6/ emerging.pdf

Goldman, S., J. Braasch, J. Wiley, A.

Graesser, and K. Brodowinska. 2012.

"Comprehending and learning from

Internet sources: Processing patterns of better and poorer learners." Reading Research Quarterly, 47(4): 356-38I.

Goulah, J. 2007. "Village voices, global visions: Digital video as a transformative foreign language learning tool." Foreign Language Annals, 40: 62-78.

Grabill, J., and T. Hicks. 2005. "Multiliteracies meet methods: The case for digital writing in English education." English Education, 37(4):30I-3II.

Gui, M., and G. Argentin. 20Ir. "Digital skills of internet natives: Different forms of digital literacy in a random sample of northern Italian high school students." New Media \& Society, I3 (6): 963-980.

Hutchison, A., B. Beschorner, and D. SchmidtCrawford. 2012. "Exploring the use of the iPad for literacy learning." Reading Teacher, 66(I): 15-23. doi:10.1002/

TRTR.oIo9o

Inoue, H., E. Naito, and M. Koshizuka. 1997. "Mediacy: what is it?" International Information and Library Review, 29(3/4): 403-413.

International Society for Technology in Education [ISTE]. 20I2. ISTE and the ISTE Standards. Retrieved from https:// www.iste.org/standards

Ivala, E., and D. Gachago. 2012. "Social media for enhancing student engagement: The use of Facebook and blogs at a university of technology." South African Journal of Higher Education, 26(I): 152-167. http:// hdl.handle.net/I0520/EJCI23970

Jewitt, C. 2014. "I2 Multimodal approaches." Interactions, images and texts: A reader in multimodality, II: 127.

Kalantzis, M., and B. Cope. 2005. Learning by design. Melbourne, Australia: Victorian Schools Innovation Commission.
Kaiser, M. 20II. "New approaches to exploiting film in the foreign language classroom." $L_{2}$ Journal, 3: 232-249.

Keengwe, J., and G. Onchwari. 2009. "Technology and early childhood education: A technology integration professional development model for practicing teachers." Early Childhood Education Journal, 37(3): 209-218. doi: I0.1007/sio643-009-034I-0

Kress, G. 2009." What is a mode?" In The Routledge handbook of multimodal analysis, edited by C. Jewitt, 54-67. Abingdon, UK: Routledge.

Kress, G.; van Leeuwen, T. 2001. Multimodal discourse: the modes and media of contemporary communication. London: Arnold.

Kurniawati, N., E. H. Maolida and, and A. G. Anjaniputra. 2018. "The Praxis of Digital Literacy in the EFL Classroom: Digital Immigrant vs Digital-native Teacher." Indonesian Journal of Applied Linguistics, 8(I): 28-37. Doi: I0.17509/ijal.v8ir.II 459

Lenhart, A., and M. Madden. 2005. "Teen content creators and consumers." Pew Internet \& American Life Project. Retrieved from www.pewinternet.org/ pdfs/PIP_Teens_Content_Creation.pdf.

Leu, D.J., C. K. Kinzer, J.L. Coiro, and D. W. Cammack. 2004. "Towards a theory of new literacies emerging from the Internet and other information and communication technologies." In Theoretical models and processes of reading (sth ed.), edited by R.B. Ruddell and N.J. Unrau, 1570-1613. Newark, DE: International Reading Association.

Leung, L., and P. Lee. 2012 "Impact of Internet Literacy, Internet Addiction Symptoms, and Internet Activities on Academic Performance." Social Science Computer Review, 30: 403.

Lopez Islas, J.R. 2013. "Digital literacy and academic success in online education for underprivileged communities : the prep@ 
net case." Ph.D. Diss., University of Texas, Austin.

Lotherington, H. 2010. "Language and the "physics" of literacy: Reassessing ${ }_{3} \mathrm{D}$ communication in $2 \mathrm{D}$ curricula." Invited presentation given at New Directions in Language Policy: Four conversations, Glendon College, York University, Toronto, Ontario, Canada.

Martin, A. 2005. "DigEuLit - A European framework for digital literacy: A progress report." Journal of eLiteracy, 2: 130-136.

Retrieved from http://www.jelit.org/65/oI/ JeLit_Paper_3I.pdf

McAdams, L. and J. Gentry. 2014. "The use of digital story expressions with adolescents to promote content area literacy." In Academic Knowledge Construction and Multimodal Curriculum Development, edited by D. Loveless, B. Griffith, M. Bérci, E. Ortlieb, and P. Sullivan, 243-255. Hershey: PA: Information Science Reference.

McClure, C.R. 1994. "Network literacy: a role for libraries." Information Technology and Libraries, I3(2): II5-I25.

Meyers, E., I. Erickson, and R. Small. 2013. "Digital literacy and informal learning environments: an introduction." Learning, media and technology, 38(4):355-367.

Modern Language Association. 2007. "Foreign languages and higher education: New structures for a changed world." Ad Hoc Committee on Foreign Languages. Profession, 234-245.

Mok, J. C. H. 2012. "Facebook and learning: Students' perspective on a course." Journal of the NUS Teaching Academy, 2(3): I3II43. Retrieved from http://www.nus.edu. sg/teachingacademy/article/lorem-ipsumdolor-2/

Morgan, H. 2014. "Focus on technology:

Enhancing instruction and communication with Twitter." Childhood Education, 90(I): 75-76. doi:10.1080/0009 4056.2014 .872522
Neelameghan, A. 1995. "Literacy, numeracy ... informacy." Information Studies, I (4): 239249.

New London Group. 1996. "A pedagogy of multiliteracies: Designing social futures.” Harvard Educational Review, 66: 60-92.

$\mathrm{Ng}, \mathrm{W} .2012$. "Can we teach digital natives digital literacy?” Computers \& Education, 59: $1065-1078$.

NMC and the European Commission. 2014. "Horizon Report Europe: 2014 Schools Edition."

Northrop, L., and E. Killeen. 2013. "A framework for using iPads to build early literacy skills." Reading Teacher, 66(7): 531-537. doi:I0.1002/TRTR.II55

Ntelioglou, M. B. Y. 20I2. "Drama pedagogies, multiliteracies and embodied learning: Urban teachers and linguistically diverse students make meaning." PhD diss., Ontario Institute for Studies in Education/University of Toronto.

Ophus, J. D. and J. T. Abbitt. 2009. "Exploring the potential and perceptions of social networking systems in university courses." Journal of Online Learning and Teaching, 5(4): 639-648. Retrieved from http://jolt. merlot.org/vol5no4/ophus_I209.pdf

Öz, H. 2015. "Investigating the relationship between foreign language learning and call attitudes among EFL freshman students." Procedia-Social and Behavioral Sciences, 176: 1041-1049.

Öz, H., M. Demirezen, and J. Pourfeiz. 2015. "Digital device ownership, computer literacy, and attitudes toward foreign and computer-assisted language learning." Procedia-Social and Behavioral Sciences, I86: 359-366.

Paesani, K. 2006. "Exercices de style. Developing multiple competences through a writing portfolio." Foreign Language Annals, 38 : 6i8-639.

Paesani, K., H. W. Allen, and B. Dupuy. 2015. A multiliteracies framework for collegiate 
foreign language teaching. Upper Saddle

River, NJ: Pearson Education.

Palalas, A. 20r.. "ESP for Busy College

Students: Is the Blend of In-Class, Online

\& Mobile Learning the Answer?" IALLT,

4I: I. retrivied from http://ialltjournal.org/

index.php/ialltjournal/article/view/130

Parra, M. L., A. Otero, R. Flores, and

M. Lavallée. 2017. "Designing a

comprehensive curriculum for advanced

Spanish heritage learners: Contributions

from the multiliteracies framework." In

$\infty$

Multiliteracies pedagogy and language

learning: Teaching Spanish to heritage

speakers, edited by G. Zapata and M.

Lacorte, 27-66). Cham, Switzerland:

Palgrave Macmillan.

Péron, M. 20ro. "Writing history in the voice of an other: Debyser's Immeuble at the advanced level." Foreign Language Annals, 43: 190-215.

Pfeifer, S.and D. Borozan. 201 r. "Fitting Kolb's learning style theory to entrepreneurship learning aims and content." International Journal of Business Research, II(2): 216-223.

Pirbhai-Illich, F., N.K.C. Turner, and T.Y. Austin. 2009. "Using digital technologies to address aboriginal adolescents' education: an alternative school intervention." Multicultural Education and Technology Journal, 3: 1 44-162.

Prensky, M. 200I. "Digital natives, digital immigrants - part I." On the Horizon, 9(5): I-6.

Rajeswaran, M. C. 2019. "Lack Of Digital Competence: The Hump In A University - English For Specific Purpose." International Journal of Scientific \& Technology Research, 8 (10): 948-956.

Raman, K. and H. Yamat. 20I4. "Barriers teachers face in integrating ICT during english lessons: A case study." The Malaysian Online Journal of Educational Technology, 2(3): II-19. Retrieved from http://files.eric.ed.gov/fulltext/EJio86402. pdf
Reinhardt, J., C. Warner, and K. Lange. 2014. "Digital games as practices and texts: New literacies and genres in an $\mathrm{L}_{2}$ German classroom." In Digital literacies in foreign and second language education, edited by $\mathrm{J}$. Pettes-Guikema and L. Williams, I59-177. San Marcos, TX: CALICO.

Rivoltella, P. C. 2008. Digital literacy: Tools and methodologies for information society. Hershey, PA: IGI Publishing.

Rowsell, J., and Walsh, M. 2or. "Rethinking literacy education in new times: multimodality, multiliteraices, and new literacies." Brock Education Journal, $2 \mathrm{I}(\mathrm{I})$ :。 $53-62$.

Sector, UNESCO Education. 2004. "The plurality of literacy and its implications for policies and programs: Position paper." Paris: United National educational, scientific and cultural organization, I3.

Simjanoska, D. K. 2017. "Mobile phones as learning and organizational tools in the ESP classroom." The Journal of Teaching English for Specific and Academic Purposes, 5( 2): 321-332. DOI:10.22190/ JTESAPI70232IK

Shuhaimi, A. S. 2004. "Multiliteracies: An exploratory study on the use of the multiliteracies approach in the teaching of English in selected perak schools." Master of Arts, Universiti Sains Malaysia.

Smythe, S., and P. Neufeld. 2010. "Podcast time': negotiating digital literacies and communities of learning in a middle years ELL classroom." Journal of Adolescent and Adult Literacy, 53(6): 488-496.

Son, J., S. Park, and M. Park. 2017. "Digital literacy of language learners in two different contexts." JALT CALL journal, I3 (2): 77-96.

Tan, J. P., and E. Mc William. 2009. "From literacy to multiliteracies: diverse learners and pedagogical practice." Pedagogies: An International Journal, 4(3): 213-225.

Tech and Law Center. 20r4. "Security of the Digital Natives.” Italy. 
Troyan, F. 2016. "Learning to mean in Spanish writing: A case study of a genre-based pedagogy for standards-based writing instruction." Foreign Language Annals, 49: 317-335.

Turner, P.M., and R.S. Carriveau. 2010. Next generation course redesign. New York: Peter Lang Publishing.

UNESCO. 1978. Records of the General Conference. 2oth Session, Vol. I. Paris: UNESCO.

UNESCO Institute for Information Technologies in Education. 201r. Digital Literacy in Education. Policy Brief, May 20Ir. http://unesdoc.unesco.org/ images/0021/002144/214485e.pdf

UNESCO Institute for statistics. 2018. Defining literacy

http://gaml.uis.unesco.org/wp-content/uploads/ sites/2/2018/12/4.6.I_07_4.6-definingliteracy.pdf

Urbančíková, N., N. Manakova, and G. Bielcheva. 2017. "Socio-Economic and Regional Factors of Digital Literacy Related to Prosperity." Quality Innovation Prosperity, 2I(2): I24-I4I.

Valdés, G. 2004. "The teaching of academic language to minority second language learners." In Bakhtinian perspectives on language, literacy and learning, edited by A. F. Ball and S. W. Freedman, 66-98. Cambridge, UK: Cambridge University Press.

Walraven, A., S. Brand-Gruwel, and H.P.A. Boshuizen. 2009. "How students evaluate information and sources when searching the World Wide Web for information." Computers \& Education, 52: 234-246.

Walsh, M. 2008. "Worlds have collided and modes have merged: classroom evidence of changed literacy practices." Literacy, 42(2): IOI-IO8.

Warner, C., and D. Richardson. 2017. "Beyond participation: Symbolic struggles with(in) digital social media in the $\mathrm{L}_{2}$ classroom." In Engaging the world: Social pedagogies and language learning, edited by S. Dubreil and S. Thorne, 199-226. Boston: Cengage.

Williams, L., L. B. Abraham, and E. D.

Bostelmann. 2014. "A survey-driven study of the use of digital tools for language learning and teaching." In Digital literacies in foreign and second language education, edited by J. P. Guikema and L. Williams, 17-67. San Marcos, TX: Calico

Yi, Y.(2014. "Possibilities and challenges of multimodal literacy practices in teaching and learning English as an Additional Language." Language and Linguistics Compass, 8(4): 158-169.

Young, C., and T. V. Rasinski. 2013. "Studentproduced movies as a medium for literacy development." Reading Teacher, 66(8): 670-675. doi:10.1002/trtr.II75

Zapata, G. 2017. “The role of digital Learning by Design instructional materials in the development of Spanish heritage learners' literacy skills." In Multiliteracies pedagogy and language learning: Teaching Spanish to heritage speakers, edited by G. Zapata and M. Lacorte, 67-Io6. Cham, Switzerland: Palgrave Macmillan.

Zhang, M. 2013. "Supporting middle school students' online reading of scientific resources: moving beyond cursory, fragmented, and opportunistic reading." Journal of Computer Assisted Learning, 29: I38-152. 